\title{
Perilaku Pencarian Informasi Tentang Parenting Pada Ibu Baru yang Bekerja (Studi Pada Stikes Bhakti Husada Mulia)
}

\section{Information Seeking Behaviour about Parenting among New Mothers Workers (a study case on Stikes Bhakti Husada Mulia)}

\author{
Lasenta Adriyana $^{1}$, Moch. Fikriansyah Wicaksono ${ }^{2}$ \\ ${ }^{1}$ Mahasiswa Manajemen Informasi dan Perpustakaan, Sekolah Pascasarjana, \\ Universitas Gadjah Mada Yogyakarta \\ ${ }^{2}$ Program Studi Ilmu Perpustakaan dan Informasi Islam, Fakultas Ushuluddin, Adab, dan \\ Dakwah, Institut Agama Islam Negeri Tulungagung \\ E-mail: lasenta16@gmail.com/fikriansyahw24@gmail.com
}

\begin{abstract}
Information becomes a necessity that cannot be separated from everyone, both in work, study, and in daily lives. The development of information is supported by the ease of internet access that is present today both for ordinary people and for an institution. In the work environment at the STIKES Bhakti Husada Mulia Madiun, the search for information using the internet is usually done, especially in meeting daily information needs. One of the most frequently sought information is about parenting carried out by new moms who work in BHM STIKES and have children under five. New moms who work cannot fully accompany their children even though the important moment of a child in his growth period at 0 to 5 years old or commonly called the child's golden age. So that information about parenting is expected to help in daily parenting. This study will analyze how the information seeking behavior about parenting by new moms who work at STIKES Bhakti Husada Mulia Madiun. The informants in this study were new moms who worked on STIKES BHM with employee status, active lecturers, lecturers who were studying further, and laboratory assistants.
\end{abstract}

Keywords: new moms; seeking information behavior; parenting; STIKES BHM.

\begin{abstract}
Abstrak
Informasi menjadi suatu kebutuhan yang tidak lepas dari setiap orang, baik dalam pekerjaan, studi, maupun dalam kehidupan sehari-harinya. Perkembangan informasi didukung dengan kemudahan akses internet yang hadir saat ini baik bagi masyarakat biasa maupun bagi sebuah institusi. Dalam lingkungan kerja di STIKES Bhakti Husada Mulia Madiun, pencarian informasi menggunakan internet sudah biasa dilakukan, terutama dalam memenuhi kebutuhan informasi sehari-hari. Salah satu informasi yang sering dicari adalah tentang parenting yang dilakukan oleh ibu baru yang bekerja pada STIKES BHM dan memiliki anak usia balita. Ibu baru yang bekerja tidak dapat mendampingi anaknya secara penuh padahal moment penting anak dalam masa pertumbuhan adalah di usia 0 sampai 5 tahun atau biasa disebut usia emas anak. Sehingga informasi tentang parenting diharap dapat membantu dalam pola asuh sehari-harinya. Tujuan Penelitian ini akan menganalisis bagaimana perilaku pencarian informasi tentang pola asuh atau parenting untuk anaknya oleh ibu baru yang bekerja di STIKES Bhakti Husada Mulia Madiun. Informan dalam penelitian ini adalah ibu baru yang bekerja pada STIKES BHM dengan status karyawan, dosen yang aktif mengajar, dosen yang sedang studi lanjut, dan laboran.
\end{abstract}

Kata kunci: ibu baru; perilaku pencarian informasi; pola asuh; STIKES BHM

\section{Pendahuluan}

Perubahan sosial, budaya dan teknologi melahirkan generasi yang semakin maju dan berkembang pola pikir serta kebiasaannya. Bukan hanya kebiasaan dalam menggunakan teknologi namun juga kebiasaan berinformasi yang mengalami perubahan besar. Informasi menjadi bagian penting dari era normal baru saat ini, karena informasi menjadi bagian yang tidak lepas dari ilmu informasi itu sendiri. Information science sendiri dapat diartikan sebagai suatu ilmu yang memproses informasi, mulai dari ditemukan, dikelola, dan disebarkan kembali (Wikipedia, 2018). Pengertian 
informasi juga telah dijelaskan pada Kamus Besar Bahasa Indonesia (kbbi.kemdikbud, 2018) sebagai penerangan, pemberitahuan, atau kabar, atau berita tentang sesuatu. Dapat disimpulkan bahwa informasi adalah suatu pemberitahuan untuk diketahui, dan dari informasi tersebut seseorang akan mendapat kabar maupun jawaban atas suatu permasalahan yang tidak diketahui sebelumnya.

Orang memiliki keterbatasan dalam menerima begitu banyak pengetahuan dalam pikirannya, termasuk pengetahuan baru yang belum diketahuinya. Kebutuhan informasi adalah proses panjang dan dapat berubah-ubah dimana pengetahuan yang diserap dapat menyebabkan munculnya kebutuhan informasi yang lain. Kebutuhan informasi juga timbul karena adanya faktor ketidakpastian, kebingungan dan kecemasan sampai fokus atau perspektif pribadi telah terbentuk, (Kuhlthau, 2009). Hal inilah yang mendasari seseorang melakukan pencarian informasi dengan berbagai akses melalui sumber informasi, agar kebutuhan informasinya dapat terpenuhi sehingga akan mengurangi rasa ketidakpastian dalam dirinya. Pencarian informasi tersebut dilakukan dengan menggunakan atau mentransfer kembali informasi yang didapat sebagai akibat dari adanya suatu kebutuhan informasi (Wilson, 1999).

Perkembangan teknologi dan sarana komunikasi saat ini banyak mempengaruhi dan menjadi penyebab pergeseran cara pencarian dalam mengakses informasi. Hal ini menyebabkan tingginya akses informasi pada internet yang dapat dilihat dari gambar berikut:

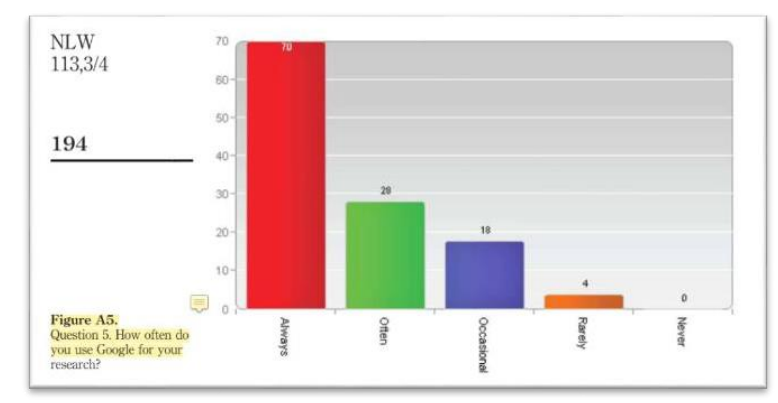

Gambar 1. Presentase Penggunaan Google di Perpustakaan

Bahkan dalam penelitian yang dilakukan Akçayir et al. (2016) dijelaskan meskipun berada dalam perpustakaan, user tetap mengakses internet untuk mendapatkan informasi. Hal ini membuktikan adanya pergeseran akses informasi karena adanya perbedaan generasi dan kebutuhan informasi.

Teknologi yang semakin maju dan berkembang tersebut memberikan peluang serta kemudahan bagi siapa saja untuk mengakses informasi. Melakukan pencarian informasi bisa dilakukan dimana saja dan kapan saja tidak terikat tempat dan waktu. Kemudahan itu memberikan banyak manfaat dan perubahan besar bagi semua kalangan yang membutuhkan informasi. Kebutuhan informasi bisa dialami oleh siapa saja, tak terkecuali oleh ibu baru yang aktif bekerja. Seperti kebutuhan informasi oleh ibu baru yang bekerja di STIKES Bhakti Husada Mulia Madiun.

STIKES BHM memiliki sebagian besar pegawai adalah wanita, hal ini berarti sebagian besar pegawai adalah ibu maupun calon ibu yang memiliki anak dan ditinggalkan dirumah untuk bekerja. Sebelumnya dalam Peraturan Pemerintah No 44 Tahun 2017 pasal 3 tentang pelaksanaan pengasuhan anak dijelaskan bahwa anak berhak untuk diasuh oleh kedua orang tuanya. Artinya setiap anak berhak mendapatkan kecukupan kebutuhan, kasih sayang, kelekatan, keselamatan, dan kesejahteraan hidup dari orang tuanya. Saat ini banyak orang tua yang bekerja demi memberikan kehidupan yang layak untuk anaknya, akibatnya anak dititipkan pada orang lain ketika orang tua bekerja, tak terkecuali oleh ibu baru. Ibu baru sendiri adalah ibu dengan status baru dikaruniai seorang anak. Ibu baru di era sekarang adalah ibu dari generasi milenial, di STIKES BHM sendiri rata-rata ibu baru adalah dengan usia 27 tahun dan baru memiliki anak pertama yang berusia balita.

Ibu baru cenderung memiliki kebutuhan informasi seputar anak, salah satunya terkait dengan informasi pola asuh atau parenting. Anak usia balita adalah anak yang sedang tumbuh pada usia emas dan membutuhkan perhatian ekstra, karena usia tersebut adalah usia yang menentukan bagaimana karakter anak saat dewasa kelak (Dinkes Kota Madiun, 2016). STIKES BHM memiliki koneksi internet yang cepat terutama untuk dosen dan karyawan, serta memiliki pusat infomasi perpustakaan yang memiliki berbagai koleksi bidang kesehatan sebagai sarana yang menunjang kebutuhan 
informasi civitas akademika. Dengan hal itu, ibu baru di STIKES BHM dapat memanfaatkan fasilitas yang ada guna menunjang kebutuhan informasinya terkait pola asuh untuk anaknya.

Jika dahulu ibu bertugas mengasuh anak dan bapak yang bekerja, saat ini hal tersebut tidak berlaku, karena baik ibu maupun bapak dapat sama-sama bekerja meskipun telah memiliki anak. Dukungan orang terdekat baik bapak maupun orang tua diperlukan agar ibu baru tetap dapat menjalankan peran sesuai fungsinya. Di satu sisi ibu bekerja dapat membantu perekonomian keluaraga, namun di sisi lain ibu bekerja berarti juga tidak dapat 24 jam dalam sehari bersama anak. Lingkungan menjadi salah satu faktor yang ikut berpengaruh terhadap kebiasaan yang dilakukan, kondisi ini akan berdampak terhadap apa yang dilakukan ibu dan ayah dalam menjalin keluarga barunya. Kebiasaan dan budaya yang ada pada lingkungan sekitar akan berdampak pada perilaku keseharian dalam berkeluarga.

\section{Metode Penelitian}

Jenis penelitian yang dilakukan adalah kualitatif dengan studi kasus terhadap ibu baru yang bekerja di STIKES Bhakti Husada Mulia Madiun, untuk mengetahui perilaku pencarian informasi sehari-hari tentang pola asuh terhadap anaknya. Penelitian kualitatif mengumpulkan dan menganalisis data berupa kata-kata dan perbuatan manusia, (Afrizal, 2016). Hal ini tidak diukur dengan angka dan tidak dapat ditetapkan sebelumnya secara jelas dan pasti. Oleh karen itu dalam kualitatif, peneliti adalah alat penelitian yang utama.

Populasi adalah seluruh pegawai baik dosen maupun karyawan, baik laki-laki maupun perempuan yang bekerja di STIKES BHM berjumlah 132 orang yaitu 37 laki-laki dan 95 perempuan. Sampel yang digunakan dalam penelitian ini berjumlah 10 orang, sebagai berikut: (1) ibu baru sebagai karyawan berjumlah 3 orang, (2) ibu baru sebagai dosen yang aktif mengajar berjumlah 3 orang, (3) ibu baru sebagai dosen dengan status studi lanjut berjumlah 3 orang, (4) ibu baru sebagai laboran berjumlah 1 orang.

\section{Kebutuhan Informasi}

Tidak adanya definisi yang sesuai dengan informasi juga diungkapkan oleh Belkin (1978) yang lebih melihat informasi sebagai suatu konsep untuk melihat dan memahami suatu fenomena. Maka informasi dilihat sebagai suatu kebutuhan atau disebut kebutuhan informasi. Kebutuhan informasi berorientasi pada konsep keinginan, permintaan, maupun tuntutan. Kebutuhan informasi sendiri diartikan sebagai suatu hal yang mendorong seseorang mencari informasi.

\section{Perilaku Pencarian Informasi}

Pencarian informasi digunakan oleh individu dalam berinteraksi baik secara manual atau melalui media informasi seperti buku, koran, dan lainnya (Solehat, Rusmono, \& Rullyana, 2016). Perilaku pencarian informasi dilakukan karena adanya kebutuhan informasi yang dirasakan oleh seseorang, sebagai konsekuensinya orang tersebut akan membuat permintaan pada sistem formal seperti perpustakaan sebagai pusat informasi atau orang lain untuk memenuhi kebutuhan informasi yang dirasakan.

\section{Pola Asuh}

Ibu menjadi orang pertama yang krusial di masa perkembangan anak karena anak sangat dekat dan membutuhkan ibu, terutama saat anak masih meminum asi, kedekatan fisik maupun emosional akan terjalin erat. Pola asuh anak menurut PP No 44 Tahun 2017 tentang pengasuhan anak adalah upaya untuk memenuhi kebutuhan akan kasih sayang, kelekatan, keselamatan, dan kesejahteraan yang menetap dan berkelanjutan demi kepentingan terbaik bagi anak.

\section{Model Kuhlthau}

Kuhlthau (1993) menggambarkan Information Search Process (ISP) sebagai "proses konstruksi yang melibatkan seluruh pengalaman seseorang, perasaan, serta pikiran dan tindakan." Model ini dikembangkan melalui studi longitudinal dengan siswa sekolah menengah dengan tahapan perasaan, pikiran, dan tindakan.

Model kuhlthau memiliki 6 tahapan diawali dengan inisiasi, seleksi, eksplorasi, formulasi, koleksi, dan presentasi. Keenam tahap ini diharapkan mampu dilewati semuanya, agar mendapatkan 
hasil yang optimal dalam melakukan pencarian informasi guna memenuhi kebutuhan informasi tersebut.

\section{Ibu Baru}

Ibu baru adalah seorang wanita yang baru saja dikaruniai anak, baik anak pertama, kedua, maupun seterusnya, namun yang disebut ibu baru adalah mereka yang baru saja memiliki anak pertama. Ibu baru biasanya memiliki banyak sekali pertanyaan terkait bagaimana cara merawat anaknya nanti. Pertanyaan-pertanyaan tersebut adalah sebuah kebutuhan informasi yang harus dipenuhi dengan cara melakukan pencarian informasi baik dari internet maupun dari mulut ke mulut. Saat ini sebagian besar ibu baru adalah generasi milenial, artinya ibu baru memiliki pengetahuan dan kebiasaan menggunakan teknologi sebagai bagian dalam perilaku pencarian informasi.

\section{Pembahasan}

Hasil dalam penelitian ini dibagi menjadi 4 sub bab yaitu; (1) kondisi geografis; (2) perilaku pencarian informasi: (3) sumber informasi; (4) karakteristik informasi.

\section{Kondisi Geografis}

Salah satu faktor yang berpengaruh terhadap kebiasaan ibu baru dalam melakukan pencarian informasi adalah kondisi geografis. Kondisi ini juga yang memperkuat adanya budaya lisan dan mendengarkan yang masih terjadi hingga saat ini. Kondisi geografis suatu lingkungan juga membentuk karakter dan kebiasaan ibu serta ayah dalam berinformasi.

Informatika sosial adalah studi yang mempelajari aspek sosial (Wikipedia, 2018). Menurut Kling (1999) informatika sosial adalah suatu studi tentang desain, penggunaan dan konsekuensi teknologi informasi yang memperhitungkan interaksi dengan konteks institusional dan budaya. Sehingga adanya ikatan antara teknologi dengan budaya menggambarkan bahwa kondisi geografis suatu lingkungan memiliki hubungan yang erat tentang perkembangan teknologi informasi dalam budaya di masyarakat. Salah satunya dalam suatu keluarga baru, antara ibu baru dan ayah yang memiliki anak berusia $0-5$ tahun.

\section{Perilaku Pencarian Informasi}

Perilaku pencarian informasi yang dilakukan ibu baru sama dengan yang terdapat pada model Kuhlthau, hanya saja tidak semua tahapan yang ada dilewati. Pada model Kuhlthau ada 6 tahap yang digambarkan seperti inisiasi, seleksi, eksplorasi, formulasi, koleksi, dan presentasi dengan 3 dimensi pada setiap tahapannya, namun pada penelitian yang telah dilakukan hanya 4 tahap dan sebagian besar melakukan 5 tahap hingga menemukan informasi yang dicari. Tahapan yang paling banyak dilewati adalah eksplorasi dan formulasi. Karena ibu menginginkan informasi yang cepat sehingga tahapan yang tidak terlalu penting langsung dilewati dan menuju tahap selanjutnya untuk segera mendapat informasi yang dicari.

\section{Sumber Informasi}

Secara keseluruhan sumber informasi yang digunakan ibu baru dalam melakukan pencarian informasi tidak lepas dari media sosial yang ada pada smarthphone. Sumber informasi yang digunakan adalah, alodokter, instagram, youtube, facebook, dan google. Jika ibu baru secara keseluruhan dari generasi milenial enggan ke perpustakaan, maka harus mulai dipikirkan untuk menyediakan konten secara online juga oleh perpustakaan, sehingga semua pengguna dapat mengakses informasi dan tidak kalah dengan media lain yang sudah lebih dahulu berfikiran maju.

\section{Karakteristik Informasi}

Karakteristik informasi yang dicari ibu ini dibedakan menjadi 3 kelompok usia anak. Pertama ibu baru dengan anak usia 0 sampai 1 tahun, di usia ini informasi yang paling banyak dicari oleh ibu baru adalah masalah kesehatan. Kedua ibu baru dengan anak usia > 1 tahun sampai 3 tahun, usia ini adalah usia paling aktif anak, karena anak mulai dapat melakukan banyak hal baru yang sebelumnya tidak bisa dilakukan. Pada usia ini hal yang menjadi konsen ibu dalam melakukan pencarian informasi adalah tentang tumbuh kembang. Ketiga ibu baru dengan usia anak 4 sampai 5 tahun, pada tahap ini 
informasi yang paling sering dicari oleh ibu adalah pendidikan, baik PAUD (Pendidikan Anak Usia Dini) atau TK (Taman Kanak-Kanak) atau jenjang selanjutnya.

Hasil yang dapat disimpulkan dari penelitian ini adalah bahwa ibu baru tidak selalu melakukan pencarian informasi dengan 6 tahapan yang ada pada model Kuhlthau. 6 tahapan yang digambarkan pada model Kuhlthau terlalu panjang ketika seorang ibu dihadapkan dengan permasalahan anak. Ibu merasa harus segera mungkin menemukan solusi untuk permasalahan yang terjadi pada anak, sehingga untuk mengikuti ke 6 tahap yang ada dirasa terlalu lama. Sehingga dapat disimpulkan bahwa tahapan yang dilakukan ibu baru dalam melakukan pencarian informasi adalah inisiasi, (eksplorasi), formulasi, koleksi, dan presentasi.

Tahap inisiasi dimulai ketika ibu menemukan masalah dan memiliki kebutuhan informasi untuk menemukan jawabannya. Setelah tahapan ini kemudian sebagian ibu melakukan tahapan eksplorasi dan sebagian ibu langsung pada tahap formulasi. Di tahap ini ibu mulai mencari informasi terkait permasalahan yang terjadi pada anak, baik melalui orang tua, dokter, bidan, maupun bacaanbacaan terkait. Sebagian besar ibu melakukan pencarian dengan bertanya pada orang tua atau dokter spesialis anak, karena dengan demikian ibu akan langsung menemukan jawaban atas permasalahan yang dihadapinya. Beberapa ibu juga melakukan pencarian melalui artikel pada sosial media agar memenuhi kebutuhan informasinya.

Tahap selanjutnya adalah koleksi, di tahap ini ibu telah mengumpulkan dan menemukan informasi untuk memenuhi kebutuhannya, sehingga dapat dikatakan informasi ibu terpenuhi. Tahap selanjutnya adalah presentasi, yaitu ibu menerapkan informasi tersebut pada anak, kemudian jika ternyata terdapat kendala maka proses pencarian informasi berulang lagi dari tahap awal, begitu seterusnya.

Hal ini berbeda dengan penelitian yang dilakukan pada penelitian terdahulu, dengan judul “Analisis Perilaku Pencarian Informasi Mengenai Breastfeeding Pada Ibu Net Generation”. Pada penelitian terdahulu tersebut hasil yang didapat adalah ibu net-gen melakukan pencarian informasi dengan tahap-tahap yang ada sesuai dengan yang ada pada model. Penelitian ini menggunakan media facebook pada pengguna ibu rumah tangga, sehingga narasumber yang diwawancara memiliki kesamaan untuk melakukan pencarian informasi secara runut pada tahapan yang sama seperti pada model pencarian informasi yang digunakan.

Pada ibu baru yang bekerja yang melakukan pencarian informasi tersebut, maka dapat ditarik kesimpulan bahwa ada kebiasaan terkait budaya dan sosial di masyarakat yang masih digunakan. Adanya budaya oral dalam kebiasaan ibu ketika mencari informasi diartikan bahwa budaya yang ada di masyarakat saat ini masih digunakan walaupun pada generasi milenial, hal ini menjadi latar belakang adanya kondisi demografi yang berbeda di masyarakat tiap wilayah.

Disamping itu, sumber informasi yang digunakan ibu baru dalam melakukan pencarian informasi juga tidak lepas dari media sosial. Hal ini membuktikan bahwa ibu baru saat ini memang dari generasi milenial yang lebih suka menemukan informasi melalui media sosial dari pada melalui buku-buku di perpustakaan. Namun karena masih adanya budaya oral, maka pencarian informasi juga lebih banyak dilakukan dengan bertanya langsung pada orang yang dianggap mampu.

\section{Simpulan}

Perilaku pencarian informasi pada ibu baru sudah sesuai dengan model Kuhltau. Dari perilaku pencarian tersebut dapat dilihat karakteristik ibu ketika melakukan pencarian informasi. Dapat disimpulkan bahwa karakteristik ibu baru dalam pencarian informasi adalah masih dipengaruhi oleh kondisi geografis lingkungannya salah satunya adalah budaya lisan yang digunakan dalam kehidupan sehari-hari generasi milenial. Baik budaya lisan primer yang diungkapkan melalui sharing, maupun budaya lisan sekunder yang terlihat melalui pemanfaatan media sosial dalam pencarian informasi. Karakteristik informasi yang dicari ibu baru terbagi menurut usia anak. Pada anak usia 0 sampai 1 tahun, informasi yang paling sering dicari oleh ibu baru adalah tentang kesehatan. Pada anak usia > 1 tahun sampai 3 tahun, informasi yang paling banyak dicari adalah tumbuh kembang anak. Kemudian pada usia anak 4 sampai 5 tahun, informasi yang paling banyak dicari ibu adalah persiapan pendidikan serta kelanjutan pendidikan bagi anak. 
Sumber informasi yang digunakan oleh ibu baru dalam pencarian informasi adalah aplikasi kesehatan seperti alodokter, aplikasi media sosial berbasis konten video dan foto seperti instagram, grup facebook, konten-konten pada youtube, serta mesin penelusur google. Dalam berinformasi kondisi lingkungan juga menjadi salah faktor yang mempengaruhi kebiasaan untuk mencari dan mendapatkan informasi. Masih diterapkannya budaya lisan baik primer maupun sekunder juga menjadi suatu hal unik yang tidak disadari selama ini. Hal ini pada akhirnya membentuk karakteristik keluarga, utamanya ibu dalam berinformasi khususnya untuk penggunaan teknologi, seperti smartphone. Penelitian ini mengungkapkan masih banyaknya ayah yang melarang ibu untuk menggunakan smarthphone saat dirumah dan hanya fokus pada anak serta suami. Hal ini menjadi kebiasaan yang juga tertanam dari kebiasaan orang tua ayah maupun ibu dalam lingkungan keluarga, sehingga kondisi demografis suatu wilayah turut menjadi pengaruh dalam kebiasaan ibu berinformasi sehari-hari.

Kebiasaan ini akhirnya menimbulkan suatu kebiasaan unik lainnya, bahwa ibu fokus dan hanya memikirkan anak serta suami saat di rumah, namun saat bekerja dan mendapatkan waktu luang, ibu memanfaatkan untuk mencari informasi sebanyak-banyaknya terkait pola asuh anak. Informasi yang telah didapat ini menjadi bekal saat kembali pada lingkungan keluarga ketika sudah pulang dari rutinitas pekerjaan. Pada kenyataannya informasi yang sudah di dapat ibu sebelumnya lebih banyak hanya menjadi bekal saja karena sebagian besar ibu lebih memilih untuk mendengarkan dan melakukan apa yang nenek, dokter anak atau orang yang lebih tau tentang dunia anak saat menghadapi masalah, utamanya pola asuh anak.

\section{Referensi}

Arlin, Putri Dwi. (2016). Analisis perilaku pencarian informasi mengenai breastfeeding pada ibu net generation (Tesis). Surabaya: Universitas Airlangga.

Baumrind, D. (1966). Effects of Authoritative Parental Control on Child Behavior, Child Development, 37(4), 887-907.

Belkin N.J., (1978), Progress in documentation: Information concepts for information science. Journal of Documentation, 34 (1), 55-85.

Case, D. O. (2012). Looking for Information (A Survey of research on Information seeking,need, and behavior (3rd ed.). Bingley: Emerald.

KBBI. (2018). Diakses dari: https://kbbi.kemdikbud.go.id/entri/informasi. Tanggal 30 April 2018.

K. Sudha. (2013). Information seeking behavior of regular ph.d scholars in gandhigram rural university. International Journal of Library \& Information Science, 3(1), 163-182.

Kling, Rob. (1999). What is social informatics and why does it matter?. D-Lib Magazine, 5(1). Koja-

Odongo, R., \& Mostert, R. (2013). Information seeking behaviour : Aconceptual framework. South African Journal of Libraries and Information Science, 72(3),45-158.

Krikelas, J. (1983). Information-seeking behaviour: patterns and concepts. Drexel Library Quarterly, 19(2), 5-20.

Kuhlthau, C. (1991). Inside the search process: information seeking from the users perspective. Journal of the American Society of information Science, 42(5), 361-371.

Kuhlthau, C. (1993). A principle of uncertainty for information seeking. Journal of Documentation, 49(4), 339-355.

Leckie'sModel, (2018). Leckie's model. Diakses dari: https://www.researchgate.net/figure/LeckiesModel_fig1_260133099. Tanggal 30 Mei 2018.

Liswiki. (2015). Information behavior theories. Diakses dari: https://liswiki.org/wiki/Information_behavior_theories. Tanggal 29 April 2018.

Liswiki. (2018). Information behaviour. Diakses dari: liswiki.org/wiki/information_behaviour_theories. Tanggal 2 Januari 2018.

Marimbi, Hanum. (2010). Tumbuh kembang, status gizi, dan imunisasi dasar pada balita. Yogyakarta: Nuha medika.

Ong, W. J. (1980). Literacy and orality in our times. Journal of Communication, (30).

Orlu, A. D. (2016). Information seeking behaviour of masters students: Affective and behavioural dimensions. Library Philosophy and Practice, (3),1-56.

Pemerintah Republik Indonesia. (2017). Peraturan Pemerintah Republik Indonesia Nomor 44 Tahun 
Palimpsest: Journal of Information and Library Science Vol. 11, Issue 1, 2020, page 26-57

2017 Tentang Pelaksanaan Pengasuhan Anak. Pdf. Diakses dari: http://hukumonline.com.Tanggal 27 Mei 2018.

Singh, K.P. \& Satija, M.P. (2006). A review of research on information seeking behaviour of agricultural scientists: International perspectives. DESIDOC Bulletin of Information Technology, 26(2), 16-30.

Sudilarsih, Feni. (2009). Buku pintar dunia batita. Yogyakarta: Gara ilmu.

Wilson, T.D. (1997). Information behaviour: An Interdisciplinary perspective. Information Processing and Management, 33, 551- 572.

Wikipedia. (2018). Informatika sosial. Diakses dari: http://id.wikipedia.org/wiki/informatika_sosial. Tanggal 31 Agustus 2018. 